\title{
The Relationship between Job Satisfaction and Job Performance: A Study on Sports Industry
}

\author{
Alpaslan Baki Ertekin \\ Faculty of Sport Sciences \\ Istanbul Gelişim University, Istanbul, Turkey \\ E-mail: aabertekin@gmail.com \\ Yeşim Avunduk (Corresponding author) \\ Administrative and Social Sciences, Faculty of Economics \\ Istanbul Ayvansaray University, Istanbul, Turkey \\ E-mail: dryavunduk@gmail.com
}

Received: August 18, $2021 \quad$ Accepted: September 15, 2021

Published: September 28, 2021

doi:10.5296/jei.v7i2.18949 URL: https://doi.org/10.5296/jei.v7i2.18949

\begin{abstract}
The aim of this research is to determine the relationship between job performance and job satisfaction of individuals working in the sports industry. The sample of the study consisted of 423 people (317 males and 106 females), who work in the sports industry in Istanbul and selected by purposeful sampling method. In the study, in addition to the personal information form, the "Minnesota Job Satisfaction Scale" developed by Weiss et al. (1967) and adapted to Turkish by Baycan (1985), the "Job Performance Scale" developed by Kirkman and Rosen (1999) to determine the job performance of employees and adapted to Turkish by Çöl (2008) were used as data collection tools. In the analysis of the data, independent t-test, ANOVA and Pearson Correlation analyses were performed. The results of the analysis determined that individuals did not differ according to their gender in both their job satisfaction levels and their job performance. It was determined that there was a significant difference in the "External Satisfaction" sub-dimension of the job satisfaction scale according to marital status, and there was a statistical difference in the "Internal Satisfaction" and "External Satisfaction" sub-dimensions of the job satisfaction scale according to the working hours of the participants in the workplace. Moreover, it was determined that there was no significant
\end{abstract}


difference according to the marital status of the participants and the duration of their work. Finally, it was determined that there was a positive and low-level relationship between the sub-dimensions of the job satisfaction scale and the job performance scale. As a result, it was determined that the job satisfaction and job performance levels of the individuals differed according to their socio-demographic characteristics, and the higher their job satisfaction, the higher their job performance.

Keywords: Sport industry, Job satisfaction, Job performance

\section{Introduction}

Organizations have to be strong and resilient to survive against developing technology, changes and increasing competition. Accordingly, these processes faced by organizations directly affect employees (Karaman et al., 2020). In other words, in today's competitive environment, standards must be maintained in order for businesses to survive in the business world. The way to achieve high productivity in organizations is to show the highest possible performance of employees within the standards (Çakır \& Gözoğlu, 2019). In this context, if we need to mention the concept of performance, it is a concept that has a certain purpose and is obtained after a planned activity and determines the result quantitatively or qualitatively (Palmer, 1993; Çalışkan \& Pekkan, 2017; Çalışkan et al., 2019). According to another definition, performance is the definition of where the employee or group performing activity can reach or what it can achieve about the intended goal related to that activity as quantity and quality (Naktiyok, 2019).

The high level of employee performance enables companies to reach their goals easily. It is very important that the employees are analysed in terms of which criteria, who will make this analysis, and at what level their performance level will be determine as higher or lower. However, the main issue is that their performance is evaluated and the evaluation results are notified to them. This situation is a necessity for a healthy execution of organizational functioning (Çakır \& Gözoğlu, 2019; Ertan, 2008). According to Borman (2004), job performance is defined as the activity shown by the employee within the importance of the duties in the job description (Gülduran \& Perçin, 2020). Job performance is the level of success that an employee performs in line with all his/her efforts to do the given job. If the employee is rewarded when he/she reaches his/her job goal, his/her job satisfaction level increases and affects the effort and success level of the work which will be given to the employee later (Yıldız et al., 2014; Ay \& Keleş, 2017). Besides, the effective and productive working of the employees within the company depends largely on their high job satisfaction. Therefore, it is an important factor that enterprises determine the factors that affect the job satisfaction of employees and make efforts to improve them (Ö. Bozkurt \& İ. Bozkurt, 2008). In this context, the concept of job satisfaction, which expresses the general attitude of individuals towards their jobs, is explained as a phenomenon that occurs when the characteristics of the job and the employee's wishes match each other and determines the employee's satisfaction with his job (Bakan \& Büyükbeşe, 2004: Bayar \& Öztürk, 2017). In other words, job satisfaction is defined as a feeling of satisfaction that emerges as a result of the harmony between the working life or the workplace conditions of the main person and a 
positive attitude towards the job he/she has (Ugboro \& Obeng, 2000; Timuroğlu \& İşcan, 2008). In general, Job Satisfaction can be defined as "a positive or negative evaluation judgment about a person's job or job status" or "the degree to which employees' needs and requests are met at the workplace". Job satisfaction, which is associated with the dimensions of individuals' love or enjoyment of their work, is affected by both situational and spiritual factors (Keller \& Semmer, 2013; Yang et al., 2014; Tekingündüz et al., 2015). Similarly, Misener et al. (1996) have stated that the dimensions related to job satisfaction are constituted wages, benefits from work, promotion opportunities, working conditions, management, colleagues and organizational experience (Eroğluer, 2011). Again, job satisfaction occurs in two forms, and these are internal and external satisfaction. While satisfaction obtained as a result of work such as wages and economic rewards are expressed as "external satisfaction", the satisfaction felt during the study, such as the sense of achievement, is expressed as "inner satisfaction" (Deniz, 2005; Özaydın \& Özdemir, 2014). In the literature, the studies about job satisfaction are generally related to job satisfaction and organizational cynicism (Chrobot-Mason, 2003; Eaton, 2000; Kahya, 2013), intention to quit (Kitapç1 et al., 2013), organizational communication (Eroğluer, 2011), emotional intelligence (Sudak \& Zehir, 2013) and organizational justice (Keklik \& Çoşkun Us, 2013). Studies on job performance have focused on the relationships between emotional intelligence, transformational leadership, self-efficacy and job satisfaction (B1yık, et al., 2017; Sony \& Mekoth, 2016; Mohamad \& Jais, 2016; Shamsuddin \& Rahman, 2014; Lindebaum, 2013; Tabatabaei et al., 2013; Yozgat et al., 2013; Platis et al., 2015, Judge et al., 2001). From this point of view, the aim of this research is to examine the relationship between job performance and job satisfaction of individuals working in the sports industry.

\section{Method}

\subsection{Research Model}

This research is a relational study designed according to the survey model, which is one of the quantitative research methods. The survey model provides a quantitative or numerical description of trends, attitudes or opinions in the population through studies on a sample selected from a population (Creswell, 2017).

\subsection{The Research Group}

A total of 423 people, 317 male (Middle-aged $=37.98 \pm 7.66$ ) and 106 female (Middle-aged = $33.83 \pm 7.56$ ), who was working in a company operating in the sports industry in Istanbul, selected by purposeful sampling method.

\subsection{Data Collection Tools}

\subsubsection{Personal Information Form}

The personal information form was created by the researcher in order to determine some personal characteristics of the employees.

\subsubsection{Minnesota Job Satisfaction Scale (MJSS)}


The Minnesota Job Satisfaction Scale, developed by Weiss et al. (1967) and adapted into Turkish by Baycan (1985), was used in the study. The scale consisted of 20 items and 2 sub-dimensions. The sub-dimensions were Internal Satisfaction (12 items) and External Satisfaction (8 items). The scale was 5-Likert type and answered as $1=$ Not Pleased; $5=$ Very Pleased.

\subsubsection{Job Performance Scale (JPS)}

The "Job Performance Scale" developed by Kirkman and Rosen (1999) to determine the job performance of employees and adapted into Turkish by Çöl (2008) and Akkoç et al., (2012) was used. The scale consisted of one dimension and four items. The scale was 5-Likert type and answered as $1=$ Strongly Disagree; 5 = Strongly Agree.

\subsection{Data Analysis}

The research data of this study were analyzed with SPSS 22 package program. It was decided whether the research data showed a normal distribution or not by looking at the skewness and kurtosis values. George and Mallery (2010) stated that the research data being between -2 and +2 is sufficient for the data to show a normal distribution. When the skewness and kurtosis values of the data in this study are examined, it is seen that the data are in the range of $-2,+2$. (Table 2). Therefore, it was assumed that the data showed a normal distribution for this study. After it was understood that the research data showed a normal distribution, the analyzes were analyzed with the $95 \%$ confidence interval t test, ANOVA and Pearson correlation test. 


\section{Results}

Table 1. Distribution of personal information of participants

\begin{tabular}{|c|c|c|c|}
\hline Variables & & f & $\%$ \\
\hline \multirow{3}{*}{ Gender } & Female & 106 & 25.1 \\
\hline & Male & 317 & 74.9 \\
\hline & Total & 424 & 100 \\
\hline \multirow{3}{*}{ Marital Status } & Married & 333 & 78.7 \\
\hline & Single & 90 & 21.3 \\
\hline & Total & 423 & 100 \\
\hline \multirow{4}{*}{ Welfare Status } & Bad & 37 & 8.7 \\
\hline & Normal & 337 & 79.7 \\
\hline & Good & 49 & 11.6 \\
\hline & Total & 423 & 100 \\
\hline \multirow{4}{*}{ Educational Status } & Highschool & 126 & 29.8 \\
\hline & University & 277 & 65.5 \\
\hline & Graduate & 20 & 4.7 \\
\hline & Total & 423 & 100 \\
\hline \multirow{5}{*}{ Working Periods } & Less than 1 year & 37 & 8.7 \\
\hline & 1-3 Years & 73 & 17.3 \\
\hline & 4-6 Years & 62 & 14.7 \\
\hline & 7 years and more & 251 & 59.3 \\
\hline & Total & 423 & 100 \\
\hline \multirow{4}{*}{ Working Conditions } & Sufficient & 239 & 56.5 \\
\hline & Partially & 161 & 38.1 \\
\hline & Sufficient & 23 & 5.4 \\
\hline & Total & 423 & 100 \\
\hline
\end{tabular}

The distribution of the personal information of the participants was given in Table 1 . According to the analysis results, $74.9 \%$ of the participants were "Male", $78.7 \%$ were "Married", 79.7\% were "Normal", 65.5\% were "University" graduates, 59.3\% were working 
for 7 years and more, $56.5 \%$ of them were found to have "Sufficient" working conditions at the workplace.

Table 2. Distribution of scale scores

\begin{tabular}{|l|l|l|l|l|l|l|l|}
\hline \multicolumn{2}{|l|}{ Sub-Dimensions } & Items & n & Mean & Sd. & Skewness & Kurtosis \\
\hline \multirow{3}{*}{ Job Satisfaction Scale } & Internal Satisfaction & 12 & 423 & 3.17 & 0.33 & -.29 & 1.43 \\
\cline { 2 - 8 } & External Satisfaction & 8 & 423 & 2.27 & 0.61 & .98 & .92 \\
\hline Job Performance Scale & Job Performance & 4 & 423 & 4.05 & 1.09 & -1.613 & 1.20 \\
\hline
\end{tabular}

Table 2 shows the distribution of research data. The average score obtained from the job performance scale was determined as 4.05. Considering the sub-dimensions of the job satisfaction scale; the mean score obtained from internal satisfaction was 3.17; The average score obtained from external satisfaction was found to be 2.27 .

Table 3. Independent t-test results of scale scores according to the gender variable

\begin{tabular}{|c|c|c|c|c|c|}
\hline & Gender & $\mathbf{n}$ & Mean \pm Ss & $\mathbf{t}$ & $\mathbf{p}$ \\
\hline \multirow{2}{*}{$\begin{array}{c}\text { Internal } \\
\text { Satisfaction }\end{array}$} & Female & 106 & $3.15 \pm 0.30$ & \multirow{2}{*}{-.387} & \multirow{2}{*}{.699} \\
\hline & Male & 317 & $3.17 \pm 0.34$ & & \\
\hline \multirow{2}{*}{$\begin{array}{c}\text { External } \\
\text { Satisfaction }\end{array}$} & Female & 106 & $2.28 \pm 0.59$ & \multirow{2}{*}{.096} & \multirow{2}{*}{.924} \\
\hline & Male & 317 & $2.27 \pm 0.61$ & & \\
\hline \multirow{2}{*}{ Job Performance } & Female & 106 & $3.96 \pm 1.11$ & \multirow{2}{*}{-.915} & \multirow{2}{*}{.361} \\
\hline & Male & 317 & $4.07 \pm 1.09$ & & \\
\hline
\end{tabular}

Table 3 shows the results of the independent samples t-test to determine whether gender affects the means obtained from the scales. According to the results of the analysis, it was determined that the effect of gender on both Job Performance Scale and Job Satisfaction Scale sub-dimensions was not statistically significant $(\mathrm{p}>0.05)$ 
Table 4. Independent t-test results of scale scores according to marital status variable

\begin{tabular}{|l|l|l|l|l|l|}
\hline & Marital Status & $\mathbf{n}$ & $\mathbf{M e a n} \pm \mathbf{S s}$ & $\mathbf{t}$ & $\mathbf{p}$ \\
\hline \multirow{3}{*}{ Internal Satisfaction } & Married & 33 & $3.16 \pm 0.34$ & \multirow{2}{*}{-.841} & \multirow{2}{*}{.401} \\
\cline { 2 - 6 } & Single & 90 & $3.19 \pm 0.29$ & & \\
\hline \multirow{3}{*}{ External Satisfaction } & Married & 33 & $2.24 \pm 0.59$ & \multirow{2}{*}{-2.110} & \multirow{2}{*035*}{} \\
\cline { 2 - 4 } & Single & 90 & $2.39 \pm 0.66$ & & \\
\hline \multirow{2}{*}{ Job Performance } & Married & 33 & $4.05 \pm 1.10$ & \multirow{2}{*}{.203} & .839 \\
\cline { 2 - 4 } & Single & 90 & $4.03 \pm 1.07$ & & \\
\hline
\end{tabular}

The results of the independent samples $t$ test, which were made to determine whether the marital status of the individuals affect their job performance and job satisfaction, are given in Table 4. According to the analysis findings, it was determined that marital status did not have an effect on job performance $(p>0.05)$. When the effect of marital status on job satisfaction sub-dimensions is examined; while marital status did not have a significant effect on internal satisfaction $(p>0.05)$; significant effect on external satisfaction was found $(p<0.05)$. It was determined that the significant difference was in favor of single individuals.

Table 5. ANOVA results of scale scores according to working period

\begin{tabular}{|c|c|c|c|c|c|}
\hline & Working Period & $\mathbf{n}$ & $\operatorname{Mean} \pm$ Ss & $\mathbf{F}$ & $\mathbf{p}$ \\
\hline \multirow{4}{*}{ Internal Satisfaction } & Less than 1 year & 37 & $3.02 \pm 0.25$ & \multirow{4}{*}{3.143} & \multirow{4}{*}{.025} \\
\hline & 1-3 Years & 73 & $3.22 \pm 0.30$ & & \\
\hline & 4-6 Years & 62 & $3.16 \pm 0.30$ & & \\
\hline & 7 Years and more & 251 & $3.17 \pm 0.35$ & & \\
\hline \multirow{4}{*}{ External Satisfaction } & Less than 1 year & 37 & $2.41 \pm 0.61$ & \multirow{4}{*}{9.155} & \multirow{4}{*}{$.000^{*}$} \\
\hline & 1-3 Years & 73 & $2.51 \pm 0.69$ & & \\
\hline & 4-6 Years & 62 & $2.11 \pm 0.35$ & & \\
\hline & 7 Years and more & 251 & $2.21 \pm 0.60$ & & \\
\hline \multirow{4}{*}{ Job Performance } & Less than 1 year & 37 & $3.60 \pm 0.70$ & \multirow{4}{*}{2.308} & \multirow{4}{*}{.176} \\
\hline & 1-3 Years & 73 & $4.07 \pm 1.03$ & & \\
\hline & 4-6 Years & 62 & $4.11 \pm 1.04$ & & \\
\hline & 7 Years and more & 251 & $4.09 \pm 1.16$ & & \\
\hline
\end{tabular}




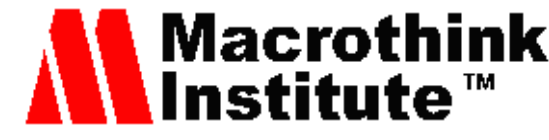

Table 5 shows the results of the ANOVA test to determine whether the working period of individuals has an effect on job performance and job satisfaction. According to the results of the analysis, it was determined that the working period did not have a significant effect on the job performance $(p>0.05)$. According to the results of the analysis, when it is considered that the working period does not have a significant effect on the sub-dimensions of job satisfaction; It has been determined that working period has a significant effect on both internal satisfaction and external satisfaction $(\mathrm{p}<0.05)$.

Table 6. Results of correlation analysis between job satisfaction and job performance scores

\begin{tabular}{|l|l|l|l|}
\hline & Internal Satisfaction & External Satisfaction & Job Performance \\
\hline Internal Satisfaction & 1 & $\mathbf{0 . 4 3 9 *}$ & $\mathbf{0 . 2 4 1 *}$ \\
\hline External Satisfaction & $\mathbf{0 . 4 3 9 *}$ & 1 & $\mathbf{0 . 3 5 9 *}$ \\
\hline Job Performance & $\mathbf{0 . 2 4 1 *}$ & $\mathbf{0 . 3 5 9 *}$ & 1 \\
\hline
\end{tabular}

Table 6 showed the analysis results of the relationship between the internal satisfaction and external satisfaction sub-dimension of the job satisfaction scale and the job performance scale. According to the results, it was determined that there was a positive and low-level relationship between the sub-dimensions of the job satisfaction scale and job performance scale $(\mathrm{p}<0.05)$.

\section{Discussion}

The main purpose of this research is to determine the relationship between the performance of individuals working in the sports industry and their job satisfaction.

In the research findings, it was determined that the gender variable did not have a significant effect on job satisfaction. In other words, the job satisfaction of individuals working in the sports industry did not differ according to gender. When the studies are examined; It has been determined that the findings of our research are in parallel with the studies conducted by Keklik and Coşkun Us (2013), Ö. Bozkurt and İ. Bozkurt (2008), and Özaydın and Özdemir (2014). The findings of the research showed that the gender of the individuals did not have a significant effect on the job performance. In other words, although the job performance levels of male individuals working in the sports industry are higher than females, this difference was not statistically significant. In the study by Özdemir et al. (2019), which examined the mediating role of person-organization fit in the effect of leader support and organizational justice perception on job performance, it was determined that there was no difference between individuals' job performances according to their gender.

When the job satisfaction levels of the participants were examined according to their marital status, it was determined that single individuals had higher scores on external satisfaction than married participants. Similarly, in a study conducted by Özaydın and Özdemir (2014), 
the results were parallel to this study. No statistically significant difference was found between the job performance levels of participants according to the marital status variable. In other words, no difference was found between individuals' job performance levels, whether they were married or single. When the studies on the subject were examined, the results of the study conducted by Özdemir et al. (2019) were in parallel with the results of this study.

When the job satisfaction levels of individuals working in the sports industry are examined according to the time they work at the workplace; It has been concluded that employees with 1-3 years of experience have higher satisfaction levels in both internal and external satisfaction sub-dimensions. The results of the study conducted by Özaydın and Özdemir (2014) were similar to the results of this study. There was no significant difference between the job performances of the individuals working in the sports industry according to the working period. In other words, although individuals working in the sports industry with 4-6 years of work experience have higher job performance levels, this difference was not statistically significant. In the study by Karaman et al. (2020) examining the effect of organizational exclusion on job performance and intention to quit, it was stated that there was no significant difference between individuals' job performance according to their services. The results of this study are in parallel with the results of the study conducted by Karaman et al. (2020). Finally, it was determined that there was a positive and low-level relationship between the sub-dimensions of the job satisfaction scale and the job performance scale. In other words, it can be said that as the job performance of individuals increased, their job satisfaction also increased.

\section{Conclusion}

As a result, it was seen that there was no difference between the job performance levels and job satisfaction of both male and female. It was determined that singles had higher external satisfaction levels than married. It was found that individuals who worked for 1-3 years in the workplace had higher levels of both internal and external satisfaction than other individuals. Finally, a positive relationship was determined between the job performance and job satisfaction of individuals working in the sports industry. In other words, it was concluded that as the job performance of individuals working in the sports industry increases, their job satisfaction also increases in parallel.

\section{References}

Akkoç, İ., Çalışkan, A., \& Turunç, Ö. (2012). The effect of development culture and perceived organizational support on job satisfaction and job performance in organizations: The mediating role of trust. Yönetim Ekonomi, 19(1), 105-135. Retrieved from https://dergipark.org.tr/tr/pub/yonveek/issue/13696/165762

Ay, F. A., \& Keleş, K. (2017). The Effect of Transactional and Transformational Leadership Styles on Intention to Leave and Job Performance. Gumushane University Journal of Health Sciences, 6(4), 193-203. 
Bakan, İ., \& Büyükbeşe, T. (2004). The Relationships Between Organizational Communication and Job Satisfaction A Field Study for Academic Organizations. Akdeniz University Journal, 7(1), 6-7.

Bayar, H. T., \& Öztürk, M. (2017). The Effect of Job Stress on Job Satisfaction: A Study on Süleyman Demirel University Research Assistants. Journal of the Faculty of Economics and Administrative Sciences of Süleyman Demirel University, 22(2), 525-546. Retrieved from ttps://dergipark.org.tr/tr/pub/sduiibfd/issue/52993/703144

Baycan, F. A. (1985). Analysis of some aspects of job satisfaction in people working in different groups (Unpublished Master of Science Thesis, Bogazici University).

Bıyık, Y., Şimşek, T., \& Erden, P. (2017). The Effect of Ethical Leadership on Employee Job Performance and Job Satisfaction. Gazi Journal of Economics and Business, 3, 59-70. Retrieved from https://dergipark.org.tr/tr/pub/gjeb/issue/27485/288383

Bozkurt, Ö., \& Bozkurt, İ. (2008). A Field Study on the Evaluation of Internal Factors Affecting Job Satisfaction in terms of Education Sector. Doğuş University Journal, 9(1), 1-18. https://doi.org/10.31671/dogus.2019.218

Çakır, A., \& Gözoğlu, Ö. F. (2019). The Effect of Perceived Institutional Reputation on Job Performance and Intention to Leave: A Study on Hospitality Businesses in Şanlıurfa. Harran Üniversitesi IIBF Dergisi, 3(4), 46-71. Retrieved from https://dergipark.org.tr/tr/pub/ econharran/issue/49062/587109

Çalışkan, A., \& Pekkan, N. Ü. (2017). The Effect of Organizational Silence on Business Performance: The Mediating Role of Ethical Climate. Hasan Kalyoncu University, Journal of Turkish Social Sciences Studies, 2(1), 4. Retrieved from http://tursbad.hku.edu.tr/tr/pub/issue/ 28703/307184

Çalışkan, A., Turunç, Ö., \& Mert, İ. S. (2019). The Mediating Role of Organizational Support in the Effect of Employee Empowerment on Job Performance. Toros University Journal of Social Sciences, 6(10), 1-21. Retrieved from https://dergipark.org.tr/tr/pub/iisbf/issue/46482/ 542709

Chrobot-Mason, L. D. (2003). Keeping the Promise: Psychological Contract Violations for Minority Employess. Journal of Managerial Psychology, 18(1), 22-45. https://doi.org/ $10.1108 / 02683940310459574$

Çöl, G. (2008). Effects of perceived empowerment on employee performance. Doğuş University Journal, 9(1), 35-46. https://doi.org/10.31671/dogus.2019.220

Cresswell, J. W. (2017). Research Design. Qualitative, Quantitative, and Mixed Methods Approaches.

Deniz, M. (2005). Bir Tutum Çeşidi Olarak İş Doyumu. Örgütsel Davranış Boyutlarından Seçmeler. Ed. Mehmet TİKİCI, Ankara, Nobel Yayını. 
Eaton, J. A. (2000). A Social Motivation Approach to Organizational Cynicism (Dissertation of Master of Arts, York University, Toronto).

Eroğluer, K. (2011). Relationships Between Organizational Communication and Job Satisfaction Elements: A Theoretical Analysis. Ege Akademik Bakış, 11(1), 121-136. https://doi.org/10.21121/eab.2011119593

Ertan, H. (2008). The Relationship Between Organizational Commitment, Job Motivation and Job Performance: A Study in Five Star Hotel Management in Antalya (Ph.D Thesis, Institute of Social Sciences, Afyonkarahisar Kocatepe University).

George, D., \& Mallery, M. (2010). SPSS for windows step by step: A simple guide and reference (17.0 Update, 10th ed.). Boston: Pearson.

Gülduran, Ç. A., \& Perçin, N. Ş. (2010). The Effect of Big Five Personality Traits on Cyberloafing Behavior and Job Performance: A Study in Hotel Businesses. Duzce University Journal of Social Sciences Institute, 10(1), 37-56.

Judge, T. A., Thoresen, C. J., Bono, J. E., \& Patton, G. K. (2001). The job satisfaction-job performance relationship: A qualitative and quantitative review. Psychological Bulletin, 127(3), 376-407. https://doi.org/10.1037/0033-2909.127.3.376

Kahya, C. (2013). Does Organizational Cynicism Affect Job Performance? Mediation Effect of Job Satisfaction. Global Journal of Economics and Business Studies, 2(3), 34-46.

Karaman, M., Yoldaş, A., \& Kılıç, B. (2020). Investigation of the Effect of Organizational Exclusion on Job Performance and Intention to Leave. Journal of Selcuk University Vocational School of Social Sciences, 23(2), 479-496. https://doi.org/10.29249/selcuksbmyd. 683115

Keklik, B., \& Us Çoşkun, N. (2013). The Effect of Perceptions of Organizational Justice on Job Satisfaction: A Study on Hospital Staff. Journal of the Faculty of Economics and Administrative Sciences of Süleyman Demirel University, 18(2), 143-161.

Keller, A., \& Semmer, N. (2013). Changes in Situational and Dispositional Factors as Predictors of Job Satisfaction. Jorunal of Vocational Behavior, 83, 88-98. https://doi.org/ 10.1016/j.jvb.2013.03.004

Kitapçı, H., Kaynak, R., \& Ökten, S. S. (2013). The Effect of Empowerment on Job Satisfaction and Intention to Leave: A Comparative Study in the Public and Private Sectors. International Review of Economics And Management, 1(1), 49-73. https://doi.org/10.18825/ iremjournal.109059

Lindebaum, D. (2013). Does emotional intelligence moderate the relationship between mental health and job performance? An exploratory study. European Management Journal, 31, 538-548. https://doi.org/10.1016/j.emj.2012.08.002 
Misener, T. R., Haddock, K. S., Gleaton, J. U., \& Ajamieh, A. R. (1996). Toward an International Measure of Job Satisfaction. Nursing Research, 45, 87-91. https://doi.org/ 10.1097/00006199-199603000-00006

Mohamad, M., \& Jais, J. (2016). Emotional Intelligence and Job Performance: A Study among Malaysian Teachers. Procedia Economics and Finance, 35, 674-682. https://doi.org/ 10.1016/S2212-5671(16)00083-6

Nartiyok, S. (2019). The Effect of Organizational Citizenship Behaviors of Hotel Employees on Job Performance: A Practice in Sivas Province. Journal of Tourism and Gastronomy Studies, 7(2), 1057-1076. https://doi.org/10.21325/jotags.2019.408

Özaydın, M. M., \& Özdemir, Ö. (2014). The Effects of Individual Characteristics of Employees on Job Satisfaction: A Public Bank Example. İşletme Araştırmaları Dergisi, 6(1), 251-281. https://doi.org/10.20491/isader.2014115974

Özdemir, O., Birer, İ., \& Akkoç, İ. (2019). The Mediating Role of Person-Organization Fit in the Effect of Leader Support and Perception of Organizational Justice on Job Performance. Toros Üniversitesi Sosyal Bilimler Dergisi, 6(10), 77-106.

Palmer, M., \& Winters, K. (1993). İnsan Kaynakları. Rota Yayınları, 39.

Platıs, Ch., Reklitis, P., \& Zimeras, S. (2015). Relation between job satisfaction and job performance in healthcare services. Procedia-Social and Behavioral Sciences, 175, 480-487. https://doi.org/10.1016/j.sbspro.2015.01.1226

Shamsuddin, N., \& Rahman, R. A. (2014). The Relationship between Emotional Intelligence and Job Performance of Call Centre Agents. Procedia-Social and Behavioral Sciences, 129, 75-81. https://doi.org/10.1016/j.sbspro.2014.03.650

Sony, M., \& Mekoth, N. (2016). The relationship between emotional intelligence frontline employee adaptability, job satisfaction and job performance. Journal of Retailing and Consumer Services, 30, 20-32. https://doi.org/10.1016/j.jretconser.2015.12.003

Sudak, M. K., \& Zehir, C. (2013). A Study on the Relationship between Personality Types, Emotional Intelligence, and Job Satisfaction. Journal of Management Sciences, 11(22), 141-165.

Tabatabaei, S., Jashani, N., Mataji, M., \& Afsar, N. A. (2013). Enhancing Staff Health and Job Performance through Emotional Intelligence and Self-Efficacy. Procedia-Social and Behavioral Sciences, 84, 1666-1672. https://doi.org/10.1016/j.sbspro.2013.07.011

Tekingündüz, S., Kurtuldu, A., \& Öksüz, S. (2015). Relationships Between Work-Family Conflict, Job Satisfaction and Job Stress. Journal of Politics, Economics and Management Studies, 3(4), 27-42.

Timuroğlu, K., \& İşcan, Ö. F. (2008). The Relationship between Narcissism and Job Satisfaction in the Workplace. Journal of Economics and Administrative Sciences, 22(2), 239-264. 
Ugboro, I., \& Obeng, K. (2000). Top management leadership, employee empowerment, job satisfaction, and customer satisfaction in total quality management organizations: an empirical study. Journal of Quality Management, 5, 247-272. https://doi.org/10.1016/ S1084-8568(01)00023-2

Weiss, D. J., Dawis, R. V., England, G. W., \& Lofquist, L. H. (1967). Manual for the Minnesota Satisfaction Questionnaire. Minnesota Studies in Vocational Rehabilitation, XXII.

Yang, J., Liu, Y., Chan, Y., \& Pan, X. (2014). The Effect of Structural Empowerment and Organizational Commitment on Chinese Nurses' Job Satisfaction. Applied Nursing Research, 27, 186-191. https://doi.org/10.1016/j.apnr.2013.12.001

Y1ldı, S., Savc1, G., \& Kapu, H. (2014). The Effect of Motivational Factors on Employees' Job Performance and Intention to Leave. Celal Bayar Üniversitesi I.I.B.F Yönetim ve Ekonomi Dergisi, 21(1). https://doi.org/10.18657/yecbu.75006

Yozgat, U., Yurtkoru, S., \& Bilginoğlu, E. (2013). Job stress and job performance among employees in public sector in Istanbul: Examining the moderating role of emotional intelligence. Procedia-Social and Behavioral Sciences, 75, 518-524. https://doi.org/10.1016/ j.sbspro.2013.04.056

Yücel, İ., \& Demirel, Y. (2013). Mevcut iş Alternatiflerinin İş Tatmini ve İşten Ayrılma İlişkisi Üzerine Etkisi: “Başka Bir Yol Daha Olmalı!”. Atatürk Üniversitesi İktisadi ve İdari Bilimler Dergisi, 27(2), 159-177.

\section{Copyright Disclaimer}

Copyright for this article is retained by the author(s), with first publication rights granted to the journal.

This is an open-access article distributed under the terms and conditions of the Creative Commons Attribution license (http://creativecommons.org/licenses/by/3.0/). 